\title{
Ecological functions provided by dung beetles are interlinked across space and time: evidence from ${ }^{15} \mathrm{~N}$ isotope tracing
}

\author{
Beatrice Nervo, ${ }^{1,4}$ Enrico Caprio, ${ }^{1}$ Luisella Celi, ${ }^{2}$ Michele Lonati, ${ }^{2}$ Giampiero Lombardi, ${ }^{2}$ \\ Gloria Falsone, ${ }^{3}$ Gabriele Iussig, ${ }^{2}$ Claudia Palestrini, ${ }^{1}$ Daniel Said-Pullicino, ${ }^{2}$ and Antonio Rolando ${ }^{1}$ \\ ${ }^{1}$ Department of Life Sciences and Systems Biology, University of Torino, Torino 10123 Italy \\ ${ }^{2}$ Department of Agricultural, Forest and Food Sciences, University of Torino, Grugliasco 10095 Italy \\ ${ }^{3}$ Department of Agricultural Sciences, University of Bologna, Bologna 40127 Italy
}

\begin{abstract}
Maintaining multiple ecological functions ("multifunctionality") is crucial to sustain viable ecosystems. To date most studies on biodiversity-ecosystem functioning (BEF) have focused on single or few ecological functions and services. However, there is a critical need to evaluate how species and species assemblages affect multiple processes at the same time, and how these functions are interconnected. Dung beetles represent excellent model organisms because they are key contributors to several ecosystem functions. Using a novel method based on the application of ${ }^{15} \mathrm{~N}$-enriched dung in a mesocosm field experiment, we assessed the role of dung beetles in regulating multiple aspects of nutrient cycling in alpine pastures over appropriate spatial (up to a soil depth of $20 \mathrm{~cm}$ ) and temporal (up to $1 \mathrm{yr}$ after dung application) scales. ${ }^{15} \mathrm{~N}$ isotope tracing allowed the evaluation of multiple interrelated ecosystem functions responsible for the cycling of dung-derived nitrogen (DDN) in the soil and vegetation. We also resolved the role of functional group identity and the importance of interactions among co-occurring species for sustaining multiple functions by focusing on two different dung beetle nesting strategies (tunnelers and dwellers). Species interactions were studied by contrasting mixed-species to single-species assemblages, and asking whether the former performed multiple functions better than the latter. Dung beetles influenced at least seven ecological functions by facilitating dung removal, transport of DDN into the soil, microbial ammonification and nitrification processes, uptake of DDN by plants, herbage growth, and changes in botanical composition. Tunnelers and dwellers were found to be similarly efficient for most functions, with differences based on the spatial and temporal scales over which the functions operated. Although mixed-species assemblages seemed to perform better than singlespecies, this outcome may be dependent on the context. Most importantly though, the different functions were found to be interconnected sequentially as reveled by analyzing ${ }^{15} \mathrm{~N}$ content in dung, soil and vegetation. Taken together, our current findings offer strong support for the contention that the link between biodiversity and ecosystem functions should be examined not function by function, but in terms of understanding multiple functions and how they interact with each other.
\end{abstract}

Key words: alpine dung beetles; biodiversity-ecosystem functioning; ecosystem functioning; insectsoil-plant interactions; mesocosms; multiple processes; stable isotope.

\section{INTRODUCTION}

Biotic communities are essential for providing ecological functions and ecosystem services to human society (Naeem et al. 2012). Most research to date has highlighted the importance of organisms for enhancing single or few ecological functions (Hooper et al. 2005, Cardinale et al. 2006). However, natural ecosystems are defined by many processes and are conserved for multiple functions ("multifunctionality") (Hector and Bagchi 2007, Gamfeldt et al. 2008, Lefcheck et al. 2015). Accumulated evidence suggests that the effect of biotic assemblages may be different, and potentially stronger, when multiple functions are analyzed together (Hector and Bagchi

Manuscript received 16 September 2016; accepted 31 October 2016. Corresponding Editor: Todd E. Dawson.

${ }^{4}$ E-mail: beatrice.nervo@gmail.com
2007, Gamfeldt et al. 2008). In the context of increasing efforts to understand the effects of diversity on multifunctionality different approaches have been developed, each of them with some pros and cons (Byrnes et al. 2014). The single functions approach (adopted in this study) considers a collection of functions and asks how many processes are achieved based on the community structure (Duffy et al. 2003). This approach may be limited or even biased if functions are analyzed in isolation and synergies among processes are ignored (Byrnes et al. 2014). Research on multifunctionality still remains scarce, and most studies have been focused on temperate grassland plants (Zavaleta et al. 2010, Mouillot et al. 2011, Maestre et al. 2012, Byrnes et al. 2014) and bacterial biofilms (Peter et al. 2011). There is therefore a critical need to empirically investigate and examine the contribution of different model systems (e.g., invertebrate and 
vertebrate species) to the complex interrelations between multiple ecosystem functions (Reiss et al. 2009, Cardinale et al. 2011, Maestre et al. 2012, Lefcheck et al. 2015) over space and time (Gagic et al. 2015).

Dung beetles (Coleoptera Scarabaeoidea) are one of the most important components of the detritivorous soil fauna associated with dung, and represent a notable example of organisms that play a key role in ecosystem functioning (Nichols et al. 2008). Through the manipulation of livestock feces for feeding and nesting processes, dung beetles contribute to dung removal, bioturbation, nutrient cycling, and plant growth enhancement (Nichols et al. 2008), that may benefit agricultural and pastoral ecosystems. They are broadly classified into three main functional groups based on their nesting strategies (Halffter and Edmonds 1982). Tunneler species dig tunnels beneath the dung pat where they bury brood balls, dweller species lay eggs and brood their larvae inside the pat or just at the soil-dung interface, wheras roller species transport dung balls some distance away from the dung pat before burial below the soil surface.

The importance of dung beetles for agro-pastoral ecosystems has been recognized and widely debated (Nichols et al. 2008). However, most empirical studies have only focused on their dung removal efficiency (Rosenlew and Roslin 2008, O’Hea et al. 2010, Beynon et al. 2012, Nervo et al. 2014, Tixier et al. 2015) or a few ecological functions (e.g., dung removal, grass growth and seed dispersal) (Slade et al. 2007, Braga et al. 2013, Slade and Roslin 2016). Moreover, very few studies have explored the effects of dung beetles on the chemical properties of soils (Yokoyama et al. 1991, Yamada et al. 2007). Soil detritus-feeding fauna is an important ecosystem component in regulating microbial abundance and community structure, and hence the processes controlling organic matter $(\mathrm{OM})$ decomposition and nutrient release (Speight et al. 1999, Bardgett and Wardle 2010). Dead OM provides both resources and habitat for different elements of the decomposer food web (Wardle 2002) that, in turn, influences ecosystem processes by controlling the availability of plant growth-limiting nutrients during OM decomposition, and consequently the aboveground vegetation community.

Based on these considerations, we assessed the role of dung beetles in regulating multiple ecosystem processes related to nutrient cycling in alpine pastures (Fig. 1), including dung removal, downward transport of dungderived nitrogen (DDN), mineralization (ammonification and nitrification) processes, nutrient uptake by plants, herbage growth, and botanical composition (sensu Allen et al. 2011). We focused on dung beetle nesting strategies by contrasting functions provided by tunnelers and dwellers, and hypothesized that (1) dung beetle functional groups influence ecosystem processes to different extents, with tunnelers being more effective than dwellers; (2) interactions of co-occurring species (mixedspecies assemblages containing four species) enhance multiple ecosystem functions more effectively than those of single-species (single-species assemblages); (3) the ecological functions are interconnected and the effects of species and species assemblages on the processes can change across different spatio-temporal scales. We tested these hypotheses by means of a mesocosm field experiment utilizing ${ }^{15} \mathrm{~N}$-enriched dung to trace the fate of

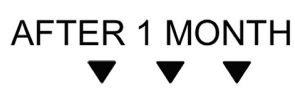

Dung removed

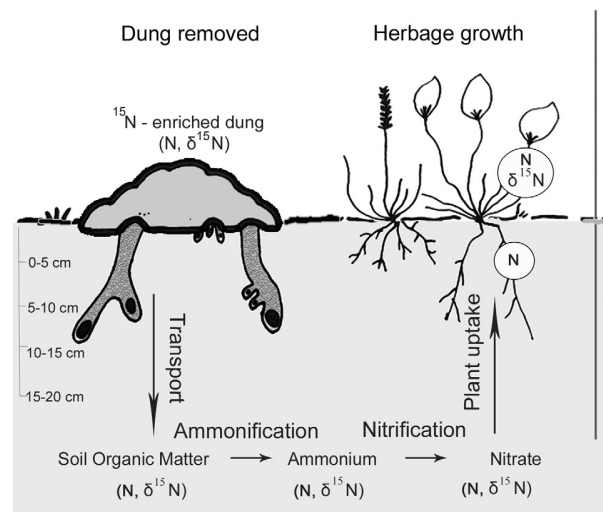

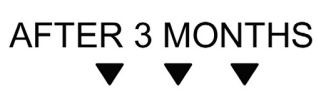

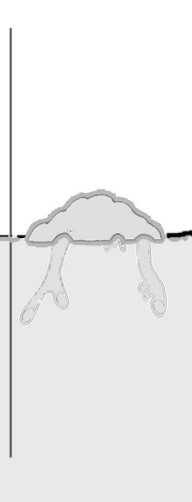

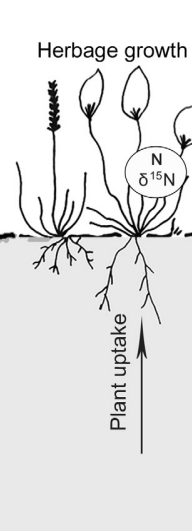

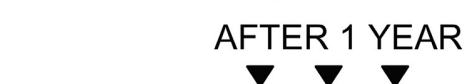

Herbage growth Botanical composition

FIG. 1. Scheme of the spatiotemporally scaled experimental set up. A total of 72 mesocosms were set in the field, subdivided into two experimental units of 36 mesocosms (six replicates) each. Dung removed, total $\mathrm{N}$ content of the residual dung, total and dungderived $\mathrm{N}$ content in soil total $\mathrm{N}$, ammonium and nitrate pools, herbage growth, and total and dung-derived $\mathrm{N}$ content in plant tissues, were evaluated after 1 month (unit 1) and after 1 yr (unit 2). Herbage growth and its total and dung-derived $\mathrm{N}$ content were determined after 3 months (unit 2). In both experimental units, half of the mesocosms (18, 3 replicates) received ${ }^{15} \mathrm{~N}$ enriched dung, while the other half received natural abundance dung. The dung pat drawn in light grey indicates the absence of analyses ( 3 months). 
DDN through the different ecosystem processes considered, and to evaluate the spatial (up to a soil depth of $20 \mathrm{~cm}$ ) and temporal (up to $1 \mathrm{yr}$ after dung application) patterns of these processes. To the best of our knowledge, there have been no previous attempts at studying the provisioning of multiple ecological functions by dung beetles using stable isotope tracers.

\section{Materials And Methods}

\section{Experimental site and collection of focal species}

After a pilot study carried out in summer 2012, the present research was carried out between June 2013 and June 2014 in an alpine pasture, dominated by graminoid species, within a protected area (Oasi Zegna) located in a Site of Community Interest (SCI IT11300002) $\left(45^{\circ} 40^{\prime} 16^{\prime \prime} \mathrm{N} ; 8^{\circ} 05^{\prime} 07^{\prime \prime} \mathrm{E}, \mathrm{N}-\mathrm{W}\right.$ Italy, about $1400 \mathrm{~m}$ a.s.1.). This study focused on Nardus-dominant grasslands in the Alps, which are widespread on N-poor areas in montane, subalpine and alpine belts (Mucina et al. 1993). Indeed, even though it is only one of the 90 pasture types in the Western Alps, it represents about $17 \%$ of total semi-natural grassland in this area (Cavallero et al. 2007). The climate is classified as sub-oceanic with a mean annual temperature and rainfall of $7.2^{\circ} \mathrm{C}$ and $1951 \mathrm{~mm}$, respectively. Inceptisol is the dominant soil order in the area (IPLA 2007). The topsoil (0-15 cm) has organic carbon (C) and total $\mathrm{N}$ contents of $148.8 \mathrm{~g} \mathrm{C} / \mathrm{kg}$ and $10.6 \mathrm{~g} \mathrm{~N} / \mathrm{kg}$, respectively.

Dung beetles were collected in this area by hand or using dung-baited pitfall traps. Four tunneler species (Anoplotrupes stercorosus [Scriba, 1796], Trypocopris pyrenaeus [Charpentier, 1825], Onthophagus fracticornis [Preyssler, 1790], Geotrupes stercorarius [Linnaeus, 1768]) and four dweller species (Teuchestes fossor [Linnaeus, 1758], Acrossus depressus [Kugelann, 1792], Parammoecius corvinus (Erichson 1848], Acrossus rufipes [Linnaeus, 1758]) were used in the experiment. These species were the most abundant of the local assemblage, which is characterized by 27 species belonging to three families and two functional groups (Scarabaeidae and Geotrupidae as tunnelers, and Aphodiidae as dwellers) (Tocco et al. 2013). Collected beetles were transferred to terraria until the start of the experiment.

\section{Mesocosm field experiment}

Dung removal, soil $\mathrm{N}$ cycling and plant community dynamics were evaluated through experimental field mesocosms. Four experimental treatments (dung pats with one and four species of tunnelers (Tun1, Tun4) or dwellers (Dwe1, Dwe4)), and a control without dung and beetles (Soil-only) were compared to a baseline control containing dung without beetles (Dung-only). Dung-only was used as a baseline control to evaluate the contribution of dung beetles in affecting ecosystem functioning. The number of individuals in each treatment with beetles was varied in order to maintain the same total beetle biomass within each functional group, as detailed in Nervo et al. (2014). The total beetle biomass in the treatments with tunnelers (Tun $1=$ Tun $4=1.634 \mathrm{~g}$ ) was double that of treatments with dwellers (Dwe1 = Dwe4 = 0.864 g), which reflected approximately the proportion of individuals between the two functional groups under natural field conditions in the study area (Tocco et al. 2013). The most abundant species in the area (Anoplotrupes stercorosus for tunnelers-Tun1, and Teuchestes fossor for dwellers-Dwe1) were adopted for the monocultures.

Fresh cattle dung, which was anthelmintic free, was collected from a closed barn in a livestock farm and homogenized. No insects or larvae were found in the dung samples. A ${ }^{15} \mathrm{~N}$-enriched dung was obtained by adding $22.84 \mathrm{~g}$ of enriched $\left(\mathrm{NH}_{4}\right)_{2} \mathrm{SO}_{4}\left(10\right.$ at. $\left.\%{ }^{15} \mathrm{~N}\right)$ dissolved in $1 \mathrm{~L}$ of deionized water to $24 \mathrm{~kg}$ of dung, while natural abundance dung was obtained by adding an equivalent amount of natural abundance $\left(\mathrm{NH}_{4}\right)_{2} \mathrm{SO}_{4}$. Prior to use, both enriched and natural abundance dung were incubated for $72 \mathrm{~h}$ at room temperature to allow for appropriate incorporation of the applied label into the dung organic matter (Shepherd et al. 2000). The initial dung had an organic $\mathrm{C}$ content of $406 \mathrm{~g} \mathrm{C} / \mathrm{kg}$, a total $\mathrm{N}$ content of $18 \mathrm{~g} \mathrm{~N} / \mathrm{kg}$, and an $\mathrm{NH}_{4}{ }^{+}$concentration of $4.56 \mathrm{mg} \mathrm{N} / \mathrm{kg}$, all expressed on a dry weight basis, while the moisture content, expressed on a fresh weight basis, was $87.2 \%$. The ${ }^{15} \mathrm{~N}$-enriched and natural abundance dung had $\delta^{15} \mathrm{~N}$ values of $1222.6 \%$ and $6.2 \%$, respectively.

Seventy-two experimental mesocosms were constructed by using cylindrical frames (PVC pipes, $40 \mathrm{~cm}$ diameter, $15 \mathrm{~cm}$ height) inserted into the ground to a depth of $10 \mathrm{~cm}$, and randomly assigned to the experimental treatments and controls. Two experimental units were considered: (1) 36 frames were used to analyze ecosystem functions after 1 month, and (2) 36 frames to analyze ecosystem functions after 3 months and $1 \mathrm{yr}$ (details of sampling are given below). Each experimental unit included six replicates, distributed in six adjacent plots (four treatments and two control/plot $\times 6$ replicates $=36$ ). The control treatments served to evaluate dung removal, $\mathrm{N}$ cycling and plant community dynamics supported by detritivourus fauna (e.g., earthworms) other than dung beetles. Prior to the beginning of the experiment, aboveground biomass within each experimental frame was cut to a height of $3 \mathrm{~cm}$ (using a Makita grass trimmer) to simulate a high grazing intensity. For each of the treatments and controls receiving dung, a $600 \mathrm{~g}$ fresh dung pat was placed on the ground in the middle of each pipe. All pipes were covered by nylon mesh cloth in order to prevent the escape and/or arrival of dung beetles, and to give all mesocosms the same experimental conditions. To evaluate the fate of the DDN in the soil profile and plant tissues, three out of the six replicates received ${ }^{15} \mathrm{~N}$ enriched dung, while the other three received natural abundance dung to account for isotope fractionation. 


\section{Dung, soil and vegetation sampling and analyses}

Dung. - Dung residues were collected after 1 month (July 2013) and $1 \mathrm{yr}$ (June 2014) from the appropriate mesocosms, and dry mass, total $\mathrm{N}$ and organic $\mathrm{C}$ were determined to evaluate the transfer and loss of material. The absolute amount of $\mathrm{N}$ in the residual dung was calculated as the product of dry mass and total $\mathrm{N}$ content of the dung residues. Mass of dung removed was expressed as a percentage of the initial dung mass as follows: [ 1 - (mass of residual dry dung/mass of initial dry dung)] $\times 100$.

Soil.-Soil samples were collected after 1 month and 1 yr. Five replicate soil cores $(1.5 \mathrm{~cm}$ in diameter) were sampled from each mesocosm beneath the dung pat, where present. Each core was divided into $5-\mathrm{cm}$ depth sections, and combined to obtain four soil samples from each mesocosm $(0-5,5-10,10-15$ and 15-20 cm). After removal of visible belowground plant parts and homogenization by passing through a $2 \mathrm{~mm}$ sieve, fresh soil sam-

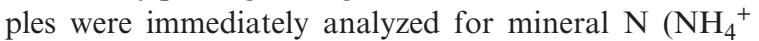
and $\mathrm{NO}_{3}{ }^{-}$) and ${ }^{15} \mathrm{~N}$ stable isotope composition of both $\mathrm{N}$ pools, while separate soil aliquots were dried, sieved $(<0.5 \mathrm{~mm})$ and analyzed for total $\mathrm{N}$, and $\delta^{15} \mathrm{~N}$ (described in Analytical methods).

Vegetation.-The vegetation features assessed throughout the study period were herbage growth, nutrient uptake by plants, and botanical composition.

Aboveground biomass was collected before the beginning of the experiment (pre-treatment phytomass), 1 month later (July 2013), 3 months later (September 2013), and 1 yr later (July 2014). In the pre-treatment aboveground samples, green biomass was manually separated from dead material (e.g., litter and old stems and leaves). In the post-treatment samples, this partition was not necessary, due to the absence of dead biomass. The green aboveground biomass was dried in a forced draft oven to a constant weight at $60^{\circ} \mathrm{C}$ to determine forage dry matter. Dried samples of aboveground biomass were ground with a Cyclotec mill (Foss Tecator, Hoganas, Sweden, $0.5 \mathrm{~mm}$ screen) and analyzed for total $\mathrm{N}$ and $\delta^{15} \mathrm{~N}$ to evaluate nutrient uptake.

Botanical composition was determined in every frame in June 2013 (pre-treatment surveys), in order to test the homogeneity of the study area, and 1 year later (June 2014) in order to assess if some changes had occurred. At each experimental frame, the vertical point-quadrate method (Daget and Poissonet 1971) was applied along $100 \mathrm{~cm}$ permanent vegetation transects. Each vegetation transect had a circular shape concentric with each experimental frame and all the species touching a steel needle were identified and recorded at every $2 \mathrm{~cm}$ interval (i.e., 50 measurements of vegetation per transect). For each, the species frequency $\left(\mathrm{SF}_{\mathrm{i}}\right)$ of occurrence (e.g., the number of occurrence within the 50 measurement point), which is an estimate of species canopy cover (Gallet and Rozé 2001, Lonati et al. 2009), was calculated. Frequency of occurrence values were converted into estimates of percentage species cover (SC). Since rare species are often missed by this method, a complete list of occasional species (e.g., the species not recorded along the transects) occurring within each experimental frame was also recorded and a minimum value of 0.3 for $\mathrm{SC}$ was assigned to each (Kohler et al. 2004, Tasser and Tappeiner 2005). All plant species recorded were attributed to two functional groups according to the Landolt indicator value for soil nutrient content (index $\mathrm{N}_{\text {Landolt; }}$, Landolt et al. 2010): oligotrophic (e.g., species growing in nutrient-poor environment, $\left.\mathrm{N}_{\text {Landolt }}=2\right)$ and mesotrophic $\left(\mathrm{N}_{\text {Landolt }}=3\right.$ or 4) species. The SC of oligotrophic and mesotrophic species was calculated for each experimental frame. The average $\mathrm{N}_{\text {Landolt }}$, weighted for $\mathrm{SC}$, within each experimental frame was also calculated according to Probo et al. 2013.

\section{Analytical methods}

Organic $\mathrm{C}$ and total $\mathrm{N}$ content of dung residues, soil and biomass samples were determined by dry combustion (NA2100; CE Instruments, Milan, Italy), while stable ${ }^{15} \mathrm{~N}$ isotope ratios of soil and biomass samples were determined by elemental analysis coupled to a continuous flow isotope ratio mass spectrometer (Delta Plus XP; Thermo Finnigan, Bremen, Germany). Concentrations of $\mathrm{NH}_{4}{ }^{+}$and $\mathrm{NO}_{3}{ }^{-}$were determined spectrophotometrically in $1 \mathrm{~mol} / \mathrm{L} \mathrm{KCl}$ extracts (1:10 soil:solution ratio) as described by Cucu et al. (2014). ${ }^{15} \mathrm{~N}$ abundances of $\mathrm{NH}_{4}{ }^{+}$ and $\mathrm{NO}_{3}{ }^{-}$in soil extracts were determined by a combination of micro-diffusion and ${ }^{15} \mathrm{~N}$ stable isotope analysis (Brooks et al. 1989, Stark and Hart 1996, Schleppi et al. 2006). Briefly, appropriate volumes of soil extract containing about $50 \mu \mathrm{g} \mathrm{N}$ were transferred into plastic diffusion tubes and the total volume adjusted to about $60 \mathrm{~mL}$ with $0.7 \mathrm{~mol} / \mathrm{L} \mathrm{KCl}$ to adjust the ionic strength of the solution. For isotopic analysis of $\mathrm{NH}_{4}^{+}$, a tefloncoated, citric acid trap was added to the diffusion tubes that were immediately sealed after addition of $0.2 \mathrm{~g} \mathrm{MgO}$, gently shaken and incubated for $7 \mathrm{~d}$ at $25^{\circ} \mathrm{C}$ to allow for complete diffusion of $\mathrm{NH}_{3}$ onto the acid trap. For isotopic analysis of $\mathrm{NO}_{3}^{-}$, acid traps were added to soil extracts that had been previously diffused for the removal of $\mathrm{NH}_{4}{ }^{+}$. After addition of $0.4 \mathrm{~g}$ Devarda's alloy to reduce $\mathrm{NO}_{3}{ }^{-}$to $\mathrm{NH}_{3}$, the tubes were resealed and allowed to diffuse for another $7 \mathrm{~d}$. All acid traps were subsequently transferred to Sn capsules, dried over concentrated $\mathrm{H}_{2} \mathrm{SO}_{4}$ and analyzed for $\delta^{15} \mathrm{~N}$ as described above.

The ${ }^{15} \mathrm{~N}$ abundances were used to determine the fraction of dung-derived $\mathrm{N}\left(f_{\mathrm{DDN}}\right)$ in soil and vegetal biomass $\mathrm{N}$ pools. We applied a mixing model: $f_{\mathrm{DDN}}=\left(\delta_{s}^{*}-\delta_{s}\right) /\left(\delta_{d}^{*}-\delta_{d}\right)$ where $\delta_{s}^{*}$ and $\delta_{s}$ are the $\delta^{15} \mathrm{~N}$ values of $\mathrm{N}$ pools in mesocosms receiving enriched or natural abundance dung, respectively, while $\delta_{d}^{*}$ and $\delta_{d}$ are the $\delta^{15} \mathrm{~N}$ values of enriched and natural abundance dung, respectively. Dung-derived N was subsequently calculated as the product of $f_{\mathrm{DDN}}$ and the $\mathrm{N}$ content of that pool. In some soil samples, the low $\mathrm{NO}_{3}{ }^{-}$concentrations 
did not allow for determination of isotopic composition by micro-diffusion (e.g., depth 10-20 cm after 1 month and depth 5-20 $\mathrm{cm}$ after $1 \mathrm{yr}$ ); however the contribution of any DDN in this pool to the total available $\mathrm{N}$ was considered to be nonetheless negligible.

\section{Statistical analyses}

The effects of different experimental treatments on the proportion of dung removed, $\mathrm{N}$ loss from dung, and soil $\mathrm{N}$ cycling were tested using Generalized Linear Mixed effects Models (GLMMs), with the plot as a random effect. Total $\mathrm{N}$ content in plant tissues, aboveground biomass, $\mathrm{SC}$ of functional groups, and average $\mathrm{N}_{\text {Landolt }}$ were also tested using GLMMs with the plot identity specified as a random effect - in these cases all the variables sampled in 2013 were specified as an offset in order to consider relative changes from the start year (Zuur et al. 2009). The experimental treatments and controls were considered separately (Tun1, Tun4, Dwe1, Dwe4, Soil-only, Dung-only), and modeled as independent categorical variables. Dung-only was used as a reference level for all the analysis. The interaction effect between the treatments and the depth (four soil layers at 0-5, 5-10, $10-15,15-20 \mathrm{~cm}$ ) was tested for all the variables related to soil samples. When the interaction effect was significant, four separate models (one for each depth) were run (e.g., see $\mathrm{NH}_{4}{ }^{+}$and ${ }^{15} \mathrm{~N}$ abundance of $\mathrm{NH}_{4}{ }^{+}$); otherwise the effect of depth was added to the model as an additive factor (e.g., see $\mathrm{NO}_{3}{ }^{-}$and ${ }^{15} \mathrm{~N}$ abundance of $\mathrm{NO}_{3}{ }^{-}$, and total $\mathrm{N}$ and DDN). The effects of mixed vs. single-species assemblages (Tun1 vs. Tun4, and Dwe1 vs. Dwe4) were evaluated within each functional group using GLMM and tested for all the dung, soil, and vegetation variables. Tun1 and Dwe1 were used as reference levels for all the analysis, respectively, for tunnelers and dwellers. Visual inspection of frequency distributions and Shapiro-Wilk tests confirmed the normality of errors in most cases. The gamma distribution was specified otherwise.

Percentage species cover of every plant species within each frame was analyzed using the Multiple Response Permutation Procedures (MRPPs; distance measure: Bray-Curtis) to test the homogeneity in the botanical composition of plant communities before the beginning of the experiment and to assess differences between treatments and controls $1 \mathrm{yr}$ later.

All analyses were carried out using R 3.0.3 (R Development Core Team 2013) with glmmADMB packages, except for MRPP analysis which were carried out using PC-ORD (McCune and Mefford 1999).

\section{RESULTS}

\section{Dung removal}

The percentage of dung removed from the soil surface was significantly higher in tunnelers (Tun1, Tun4) than in the baseline control (Dung-only) after 1 month, and in both functional groups after 1 yr (Tables 1 and 2). On average, tunnelers removed about $49 \%$ and dwellers $24 \%$ of the dung after 1 month, $80 \%$ and $84 \%$, respectively, after 1 yr.

\section{Transport of dung-derived nitrogen into the soil}

The presence of dung beetles (Tun1, Tun4, Dwe1, Dwe4) led to higher total nitrogen (N) loss from residual dung with respect to baseline controls (Dung-only) after 1 month and 1 yr. Similarly, after both 1 month and 1 year, organic $\mathrm{C}$ applied with the dung pat was lost to a greater extent in the presence of dung beetles with respect to the control (Tables 1 and 2). Total $\mathrm{N}$ in the soil was not influenced by treatments (Table 1), but decreased with soil depth (Table 3). The fraction of total soil DDN was relatively low, with values $<10 \%$. Nevertheless, the amount of total DDN was significantly greater in all treatments with respect to controls at all soil depths after 1 month and, conversely, significantly smaller (with the exception of Dwe4) at the 0-5 cm depth after 1 yr (Tables 1 and 3).

\section{Mineralization processes (ammonification and nitrification)}

Total soil $\mathrm{NH}_{4}{ }^{+}$concentrations generally showed a decreasing trend with soil depth and time (Fig. 2). $\mathrm{NH}_{4}{ }^{+}$ content in the first $10 \mathrm{~cm}$ was higher in controls (Dung-only) with respect to the controls without dung (Soil-only) after 1 month, while no significant differences were observed at greater depths (Fig. 2A). In some cases the presence of dung beetles (Tun1, Tun4, Dwe1 and Dwe4 at different depths) significantly increased the concentrations of both total and dung-derived $\mathrm{NH}_{4}{ }^{+}$with respect to Dung-only after 1 month (Table 1, Fig. 2A).

After $1 \mathrm{yr}, \mathrm{NH}_{4}{ }^{+}$concentrations were greater in Soil-only, Tun 1 and Tun4 than in Dung-only, but mainly limited to the $0-5 \mathrm{~cm}$ depth (Table 1, Fig. 2B). Tun4 tended to have higher dung-derived $\mathrm{NH}_{4}{ }^{+}$concentrations compared to Dung-only at $0-5$ and $15-20 \mathrm{~cm}$, while Dwe4 showed an opposite trend in correspondence of the first soil layer.

Total $\mathrm{NO}_{3}{ }^{-}$concentrations also showed a decreasing trend with soil depth and time (Fig. 2). Similar $\mathrm{NO}_{3}{ }^{-}$concentrations were observed in Soil-only and Dung-only along the soil profile after 1 month. In presence of dung beetles (both tunnelers and dwellers), $\mathrm{NO}_{3}{ }^{-}$concentrations were significantly higher with respect to Dung-only in all soil layers after 1 month (Table 1, Fig. 2A). Although total $\mathrm{NO}_{3}{ }^{-}$concentrations were relatively low and decreased rapidly with soil depth, DDN contributed significantly to the total $\mathrm{NO}_{3}{ }^{-}$pool in the first two soil layers $\left(67 \%\right.$ and $45 \%$ of total $\mathrm{NO}_{3}{ }^{-}$at $0-5$ and $5-10 \mathrm{~cm}$, respectively) after 1 month. Dung-derived $\mathrm{NO}_{3}{ }^{-}$concentrations at $0-5 \mathrm{~cm}$ were significantly higher in all the treatments with dung beetles with respect to the baseline controls, and only in Tun4 at 5-10 cm (Table 1, Fig. 2A). Total availability of $\mathrm{NH}_{4}{ }^{+}$and $\mathrm{NO}_{3}{ }^{-}$has been especially 
TABLE 1. Effects of experimental treatments on function variables over space and time.

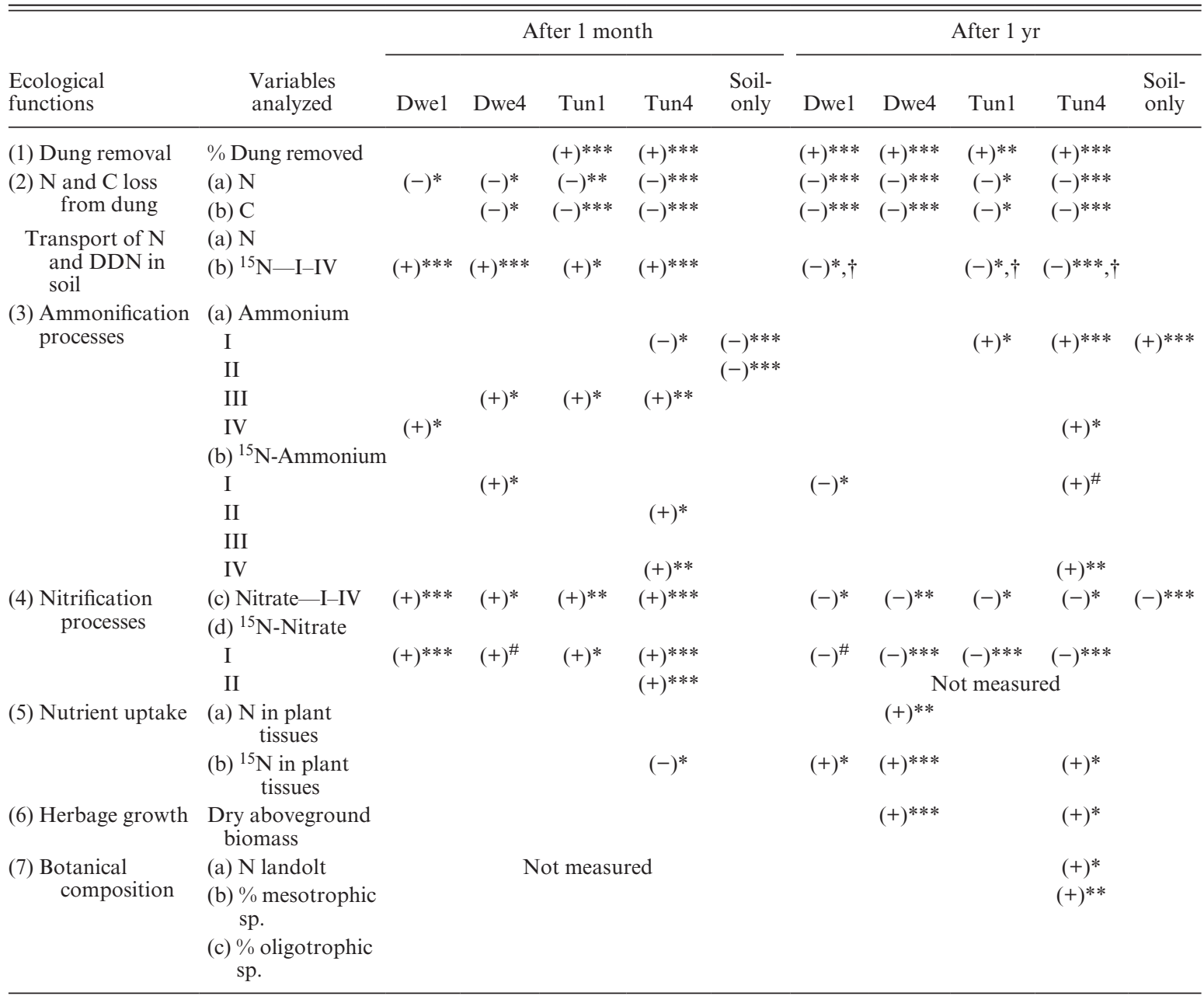

Notes: Results of GLMMs comparing functions between treatments and controls (Dung-only is the reference category) after 1 month and 1 yr. Results of herbage growth and nutrient uptake after 3 months, not presented in the table, showed higher DDN uptake in Dwe4 and Tun4 compared to Dung-only.

The symbols in parenthesis "+" or "-" refer to the model parameter estimates and indicate if the correlations are positive or negative, while "*" refers to the $P$-values.

Significance codes: ${ }^{* * *} P<0.001 ;{ }^{* *} P<0.01 ;{ }^{*} P<0.05 ;{ }^{*} P=0.05$.

$\dagger$ Results refer only to the $0-5 \mathrm{~cm}$ soil layer. I, II, III, IV refer to the four depths considered.

TABLE 2. Dung removal, nitrogen and carbon loss from the dung.

\begin{tabular}{|c|c|c|c|c|c|c|c|}
\hline \multirow{2}{*}{\multicolumn{2}{|c|}{$\begin{array}{l}\text { Experimental treatments } \\
\text { and controls }\end{array}$}} & \multicolumn{3}{|c|}{ After 1 month } & \multicolumn{3}{|c|}{ After $1 \mathrm{yr}$} \\
\hline & & $\begin{array}{c}\text { Dung } \\
\text { removed } \\
(\% \text { initial d.w.) }\end{array}$ & $\begin{array}{l}\text { Total } \mathrm{N} \text { in } \\
\text { residual } \\
\text { dung }(\mathrm{g} \mathrm{N})\end{array}$ & $\begin{array}{l}\text { Organic C } \\
\text { in residual } \\
\text { dung }(\mathrm{g} \mathrm{C})\end{array}$ & \begin{tabular}{l}
\multicolumn{1}{c}{ Dung } \\
removed $(\%$ \\
initial d.w.)
\end{tabular} & $\begin{array}{l}\text { Total } \mathrm{N} \text { in } \\
\text { residual } \\
\text { dung }(\mathrm{g} \mathrm{N})\end{array}$ & $\begin{array}{c}\text { Organic } C \text { in } \\
\text { residual } \\
\text { dung }(\mathrm{g} \mathrm{C})\end{array}$ \\
\hline Controls & Dung-only & $13 \pm 1.5$ & $1.49 \pm 0.26$ & $26.26 \pm 2.36$ & $58 \pm 12$ & $0.77 \pm 0.37$ & $10.71 \pm 4.97$ \\
\hline \multirow[t]{2}{*}{ Dwellers } & Dwe1 & $23 \pm 7$ & $1.13 \pm 0.14$ & $22.11 \pm 2.10$ & $83 \pm 5$ & $0.35 \pm 0.13$ & $4.86 \pm 1.60$ \\
\hline & Dwe4 & $24 \pm 12$ & $1.13 \pm 0.17$ & $21.79 \pm 3.52$ & $85 \pm 4$ & $0.27 \pm 0.08$ & $4.24 \pm 1.33$ \\
\hline \multirow[t]{2}{*}{ Tunnelers } & Tun1 & $41 \pm 20$ & $1.00 \pm 0.36$ & $17.77 \pm 5.99$ & $70 \pm 8$ & $0.56 \pm 0.09$ & $7.70 \pm 1.17$ \\
\hline & Tun4 & $57 \pm 33$ & $0.66 \pm 0.54$ & $11.88 \pm 9.55$ & $90 \pm 8$ & $0.24 \pm 0.12$ & $3.38 \pm 1.70$ \\
\hline
\end{tabular}

Notes: Dung removed expressed as the percentage of initial dry dung weight (d.w.), total $\mathrm{N}$ and organic $\mathrm{C}$ in the residual dung after 1 month and $1 \mathrm{yr}$ for dwellers, tunnelers and controls. Data are means \pm SE. 
TABLE 3. Soil nitrogen over space and time.

\begin{tabular}{|c|c|c|c|c|c|c|c|}
\hline & \multirow[b]{2}{*}{ Treatment } & \multicolumn{3}{|c|}{ After 1 month } & \multicolumn{3}{|c|}{ After $1 \mathrm{yr}$} \\
\hline & & $\begin{array}{l}\text { Total N } \pm \mathrm{SE} \\
\quad(\mathrm{g} \mathrm{N} / \mathrm{kg})\end{array}$ & $\begin{array}{l}\mathrm{DDN} \pm \mathrm{SE} \\
(\mathrm{g} \mathrm{N} / \mathrm{kg})\end{array}$ & $\mathrm{DDN} \%$ & $\begin{array}{l}\text { Total N } \pm \text { SE } \\
\quad(\mathrm{g} \mathrm{N} / \mathrm{kg})\end{array}$ & $\begin{array}{l}\mathrm{DDN} \pm \mathrm{SE} \\
(\mathrm{g} \mathrm{N} / \mathrm{kg})\end{array}$ & $\mathrm{DDN} \%$ \\
\hline \multirow{6}{*}{$\begin{array}{l}\text { Depth } \\
0-5 \mathrm{~cm}\end{array}$} & Dung-only & $10.58 \pm 0.54$ & $0.32 \pm 0.16$ & 3.0 & $13.08 \pm 0.80$ & $1.43 \pm 0.56$ & 11.0 \\
\hline & Dwe1 & $10.93 \pm 0.21$ & $0.75 \pm 0.33$ & 6.9 & $13.57 \pm 0.64$ & $1.34 \pm 0.28$ & 9.9 \\
\hline & Dwe4 & $10.57 \pm 0.61$ & $0.69 \pm 0.05$ & 6.5 & $13.38 \pm 0.76$ & $1.43 \pm 0.35$ & 10.7 \\
\hline & Tun1 & $10.05 \pm 0.30$ & $0.45 \pm 0.13$ & 4.5 & $12.43 \pm 0.61$ & $0.60 \pm 0.06$ & 4.8 \\
\hline & Tun4 & $10.77 \pm 0.45$ & $0.86 \pm 0.16$ & 8.0 & $12.28 \pm 0.60$ & $0.98 \pm 0.32$ & 8.0 \\
\hline & Soil-only & $10.27 \pm 0.25$ & - & - & $11.12 \pm 0.70$ & - & - \\
\hline \multirow{6}{*}{$\begin{array}{l}\text { Depth } \\
5-10 \mathrm{~cm}\end{array}$} & Dung-only & $6.67 \pm 0.66$ & $0.06 \pm 0.04$ & 1.0 & $8.12 \pm 0.45$ & $0.12 \pm 0.03$ & 1.4 \\
\hline & Dwe1 & $6.05 \pm 0.44$ & $0.09 \pm 0.03$ & 1.5 & $8.2 \pm 0.63$ & $0.13 \pm 0.02$ & 1.6 \\
\hline & Dwe4 & $6.18 \pm 0.26$ & $0.04 \pm 0.01$ & 0.7 & $8.22 \pm 0.54$ & $0.17 \pm 0.02$ & 2.0 \\
\hline & Tun1 & $6.57 \pm 0.60$ & $0.12 \pm 0.06$ & 1.8 & $7.75 \pm 0.46$ & $0.15 \pm 0.02$ & 2.0 \\
\hline & Tun4 & $6.73 \pm 0.54$ & $0.16 \pm 0.04$ & 2.3 & $8.15 \pm 0.54$ & $0.11 \pm 0.02$ & 1.3 \\
\hline & Soil-only & $6.47 \pm 0.34$ & - & - & $6.85 \pm 0.55$ & & - \\
\hline \multirow{6}{*}{$\begin{array}{l}\text { Depth } \\
\qquad 10-15 \mathrm{~cm}\end{array}$} & Dung-only & $5.55 \pm 1.38$ & $0.01 \pm 0.00$ & 0.2 & $5.23 \pm 0.52$ & $0.05 \pm 0.02$ & 1.0 \\
\hline & Dwe1 & $4.4 \pm 0.28$ & $0.04 \pm 0.02$ & 1.0 & $6.07 \pm 0.49$ & $0.05 \pm 0.01$ & 0.9 \\
\hline & Dwe4 & $4.42 \pm 0.33$ & $0.03 \pm 0.01$ & 0.6 & $5.63 \pm 0.62$ & $0.08 \pm 0.01$ & 1.5 \\
\hline & Tun1 & $4.58 \pm 0.75$ & $0.03 \pm 0.02$ & 0.6 & $5.63 \pm 0.42$ & $0.08 \pm 0.02$ & 1.5 \\
\hline & Tun4 & $4.93 \pm 0.58$ & $0.09 \pm 0.01$ & 1.8 & $5.48 \pm 0.30$ & $0.07 \pm 0.02$ & 1.4 \\
\hline & Soil-only & $4.18 \pm 0.40$ & - & - & $4.48 \pm 0.32$ & - & - \\
\hline \multirow{6}{*}{$\begin{array}{l}\text { Depth } \\
\quad 15-20 \mathrm{~cm}\end{array}$} & Dung-only & $3.80 \pm 0.56$ & $0.00 \pm 0.00$ & 0.1 & $4.07 \pm 0.44$ & $0.03 \pm 0.01$ & 0.7 \\
\hline & Dwe1 & $5.12 \pm 1.67$ & $0.04 \pm 0.03$ & 0.8 & $4.48 \pm 0.29$ & $0.03 \pm 0.00$ & 0.7 \\
\hline & Dwe4 & $4.54 \pm 1.17$ & $0.04 \pm 0.01$ & 0.9 & $4.06 \pm 0.53$ & $0.06 \pm 0.03$ & 1.6 \\
\hline & Tun1 & $4.28 \pm 0.97$ & $0.03 \pm 0.01$ & 0.6 & $4.28 \pm 0.41$ & $0.03 \pm 0.00$ & 0.7 \\
\hline & Tun4 & $3.58 \pm 0.46$ & $0.04 \pm 0.00$ & 1.0 & $4.32 \pm 0.39$ & $0.04 \pm 0.00$ & 0.9 \\
\hline & Soil-only & $3.17 \pm 0.36$ & - & - & $3.1 \pm 0.21$ & - & - \\
\hline
\end{tabular}

Note: Concentrations of total and dung-derived nitrogen (DDN) in soil at the four different depths $(0-5,5-10,10-15,15-20 \mathrm{~cm})$ after 1 month and 1 yr from dung pat deposition.

enhanced in the first soil layer $(0-5 \mathrm{~cm})$ by the mixedspecies assemblages of tunnelers and dwellers (Fig. 2A).

An opposite trend between treatments and controls was observed after 1 year, where higher $\mathrm{NO}_{3}{ }^{-}$concentrations were measured in Dung-only with respect to both Soil-only and amended treatments in the presence of dung beetles, along the whole soil profile (Table 1, Fig. 2B). After 1 yr, DDN still contributed around 33\% of the total $\mathrm{NO}_{3}{ }^{-}$pool in the $0-5 \mathrm{~cm}$ soil depth, but the trend reversed, because dung-derived $\mathrm{NO}_{3}{ }^{-}$concentrations were significantly lower in all treatments with respect to the baseline controls (Table 1, Fig. 2B).

\section{Nutrient uptake by plants}

No differences in total $\mathrm{N}$ uptake by plants were observed between treatments and baseline controls over time (except for Dwe4 after $1 \mathrm{yr}$ ). DDN on average contributed about $39 \%$ of the total $\mathrm{N}$ uptake by the plants after 1 month, $27 \%$ after 3 months and $14 \%$ after $1 \mathrm{yr}$ (Table 1, Fig. 3). The presence of dung beetles did not influence the uptake of DDN after 1 month, except for Tun4 that showed lower DDN uptake compared to Dung-only. In contrast, Tun 4 and Dwe4 after 3 months, and Dwe1, Dwe4 and Tun4 after 1 yr, showed a significantly greater uptake of DDN with respect to the baseline controls (Table 1, Fig. 3).

\section{Herbage growth}

No differences in aboveground biomass were detected among treatments and baseline controls after one and 3 months. However, herbage growth was significantly greater in Tun4 and Dwe4 compared to Dung-only after 1 yr (Table 1, Fig. 3).

\section{Botanical composition}

The sward of the study area was dominated by oligotrophic species (mainly represented by Nardus stricta, Avenella flexuosa, and Potentilla erecta) and few mesotrophic species (mainly represented by Festuca nigrescens and Carex pilulifera). The species cover of plants (SC) was homogeneous over the study area before the beginning of the experiment (Table 4). However, MRPP analysis highlighted some changes in the plant species cover after $1 \mathrm{yr}$ in Soil-only $(t=-3.32 ; P=0.004)$ and Dung-only $(t=-1.92 ; P=0.040)$ compared to Tun4. Both the average $\mathrm{N}$ Landolt index, and SC of mesotrophic species increased significantly in Tun 4 compared to Dung-only, while the 

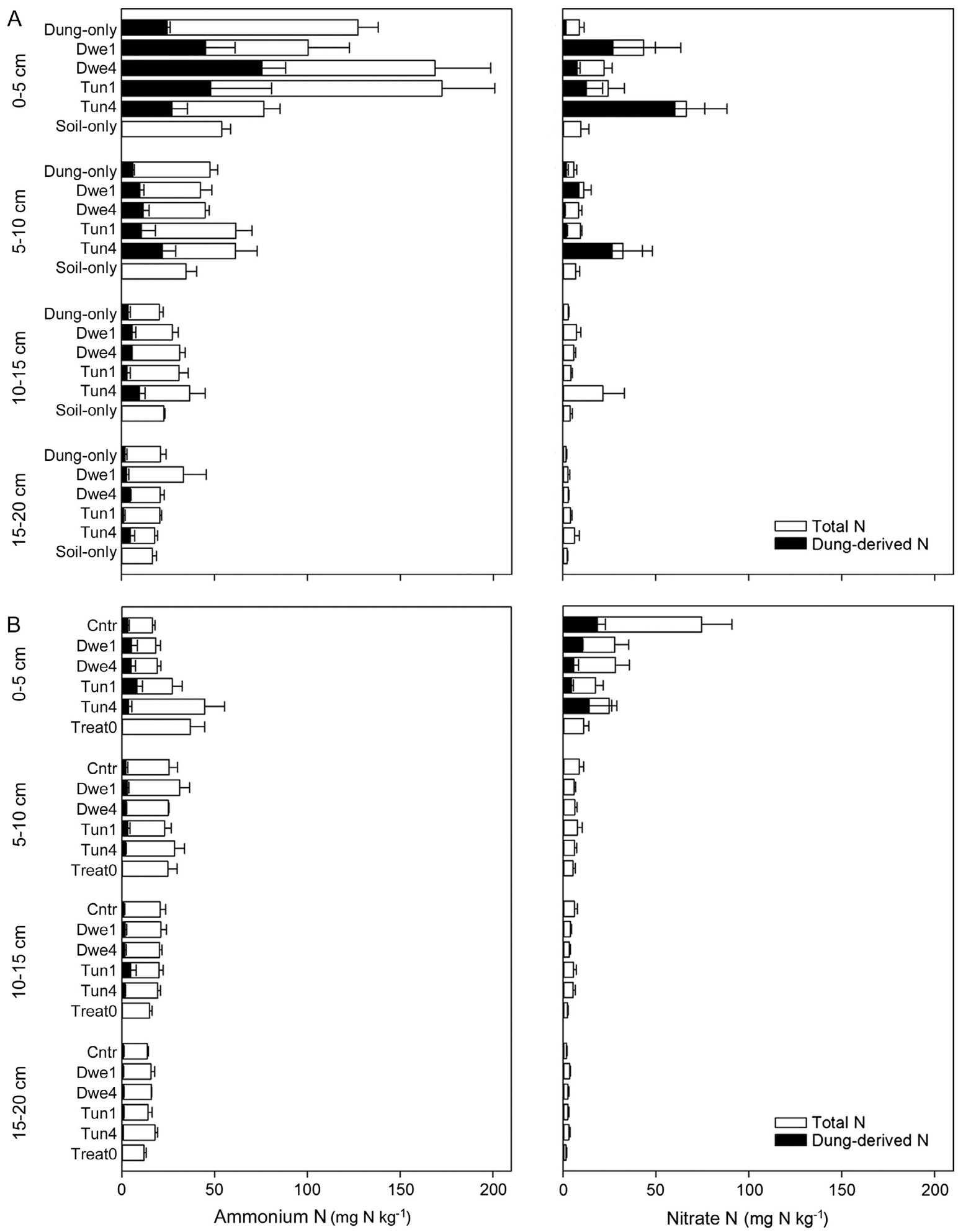

FIG. 2. Soil concentrations of ammonium and nitrate over space and time. Total (white bars \pm SE) and dung-derived (black bars $\pm \mathrm{SE}$ ) soil mineral nitrogen concentrations $\left(\mathrm{NH}_{4}{ }^{+}, \mathrm{NO}_{3}{ }^{-}\right)$at the four soil depths after (A) 1 month and (B) 1 yr. Soil-only shows no black bars because they were dung-free mesocosms. Black bars are only shown for dung-derived $\mathrm{NO}_{3}{ }^{-}$for the first two soil layers $(0-5 \mathrm{~cm}, 5-10 \mathrm{~cm})$ after 1 month, and for the first layer $(0-5 \mathrm{~cm})$ after 1 year because the low $\mathrm{NO}_{3}^{-}$concentrations prevented isotopic analyses. 


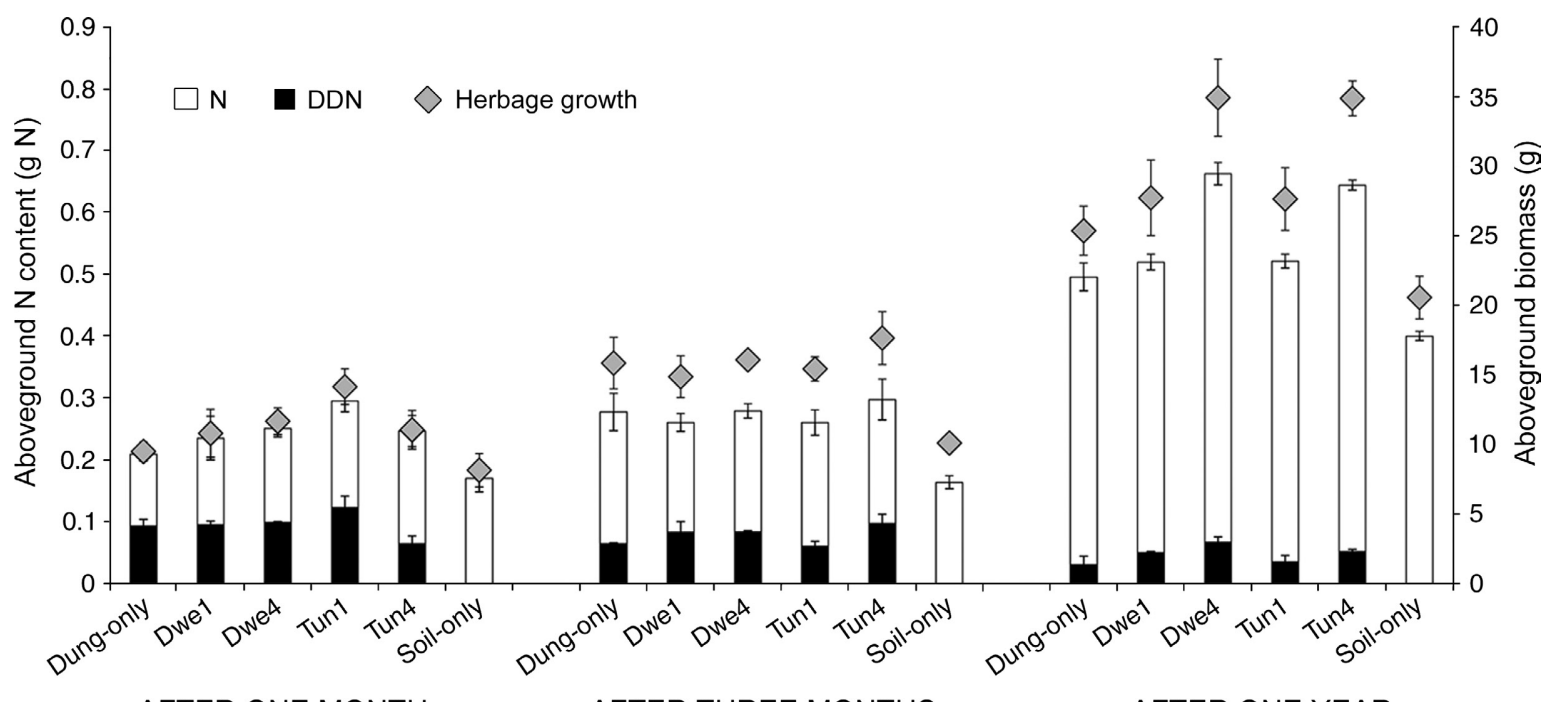

AFTER ONE MONTH

AFTER THREE MONTHS

AFTER ONE YEAR

FIG. 3. Variation of plant tissue nitrogen content and plant biomass over time. Total (white bars \pm SE) and dung-derived (black bars \pm SE) nitrogen content in aboveground plant tissues and plant growth (grey plots \pm SE) after 1 month, 3 months and 1 yr. Soil-only shows no black bars because they were dung-free mesocosms.

SC of oligotrophic species did not differ between treatments and baseline controls (Table 1).

\section{Single vs. mixed-species assemblages}

In most cases mixed-species assemblages performed better than single-species ones (Table 5). Tun4 removed significantly higher percentages of dung, enhanced $\mathrm{N}$ and $\mathrm{C}$ loss from dung, and increased the incorporation of DDN along the soil profile compared Tun1 after 1 month.

At the same time, total $\mathrm{NH}_{4}{ }^{+}$concentrations were significantly lower in Tun 4 compared to Tun 1 at $0-5 \mathrm{~cm}$, while the dung-derived $\mathrm{NH}_{4}{ }^{+}$concentrations significantly increased between 5 and $20 \mathrm{~cm}$. Total $\mathrm{NO}_{3}{ }^{-}$and dungderived $\mathrm{NO}_{3}{ }^{-}$concentrations were significantly higher in Tun4 compared to Tun1 along the soil profile (Table 5). After $1 \mathrm{yr}$, Tun 4 removed significantly higher percentages of dung, reduced $\mathrm{N}$ loss from dung, and increased

TABle 4. $P$-values of the Multiple Response Permutation Procedures (MRPPs; distance measure: Bray-Curtis). Analyses performed to test differences in botanical composition between treatments and controls before the beginning of the experiment.

\begin{tabular}{ccccc}
\hline \hline \multicolumn{4}{c}{ Botanical composition } & \\
\hline $\begin{array}{c}\text { Dung- } \\
\text { only }\end{array}$ & $\begin{array}{l}\text { Soil- } \\
\text { only }\end{array}$ & Dwe1 & Dwe4 & Tun1 \\
\hline
\end{tabular}

\begin{tabular}{llllll}
\hline $\begin{array}{l}\text { Dung-only } \\
\text { Soil-only }\end{array}$ & 0.914 & & & & \\
Dwe1 & 0.820 & 0.980 & & & \\
Dwe4 & 0.439 & 0.689 & 0.521 & & \\
Tun1 & 0.823 & 0.923 & 0.876 & 0.754 & \\
Tun4 & 0.574 & 0.746 & 0.523 & 0.675 & 0.783 \\
\hline
\end{tabular}

concentrations of total $\mathrm{NH}_{4}^{+}$, dung-derived $\mathrm{NH}_{4}^{+}$, and dung-derived $\mathrm{NO}_{3}{ }^{-}$at $0-5 \mathrm{~cm}$ compared to Tun1.

DDN uptake by plants was significantly lower in Tun 4 than Tun 1 after 1 month, but this relationship reversed after 3 months and 1 yr. Herbage growth, $\mathrm{N}$ Landolt index, and the SC of mesotrophic species significantly increased after $1 \mathrm{yr}$ in Tun 4 compared to Tun 1 (Table 5).

Dwe4 significantly increased dung-derived $\mathrm{NO}_{3}{ }^{-}$concentrations at $0-10 \mathrm{~cm}$ compared to Dwe1 after 1 month. After $1 \mathrm{yr}$, Dwe4 showed significantly higher dungderived $\mathrm{NH}_{4}{ }^{+}$concentrations at $0-5 \mathrm{~cm}$, and lower dungderived $\mathrm{NO}_{3}{ }^{-}$. Herbage growth was significantly higher in Dwe4 compared to Dwe1. DDN uptake by plants was significantly higher in Dwe4 compared to Dwe1 after 1 month, 3 months and 1 yr (Table 5).

\section{Discussion}

Identifying the best way to evaluate ecosystem functions simultaneously is a core question for current biodiversity-ecosystem functioning (BEF) research (Byrnes et al. 2014). In this study, we reviewed how functional groups and species assemblages simultaneously affect multiple processes, and how these functions are interconnected across space and time. Below, we respond to the three hypotheses presented in the introduction, before turning to the general implications of our study on BEF research.

\section{Tunnelers and dwellers are similarly efficient for most of the functions}

Tunnelers and dwellers were found to be similarly efficient for most of the functions, with some differences based on spatial and temporal scales over which the 
TABLE 5. Effects of mixed vs. single-species assemblages.

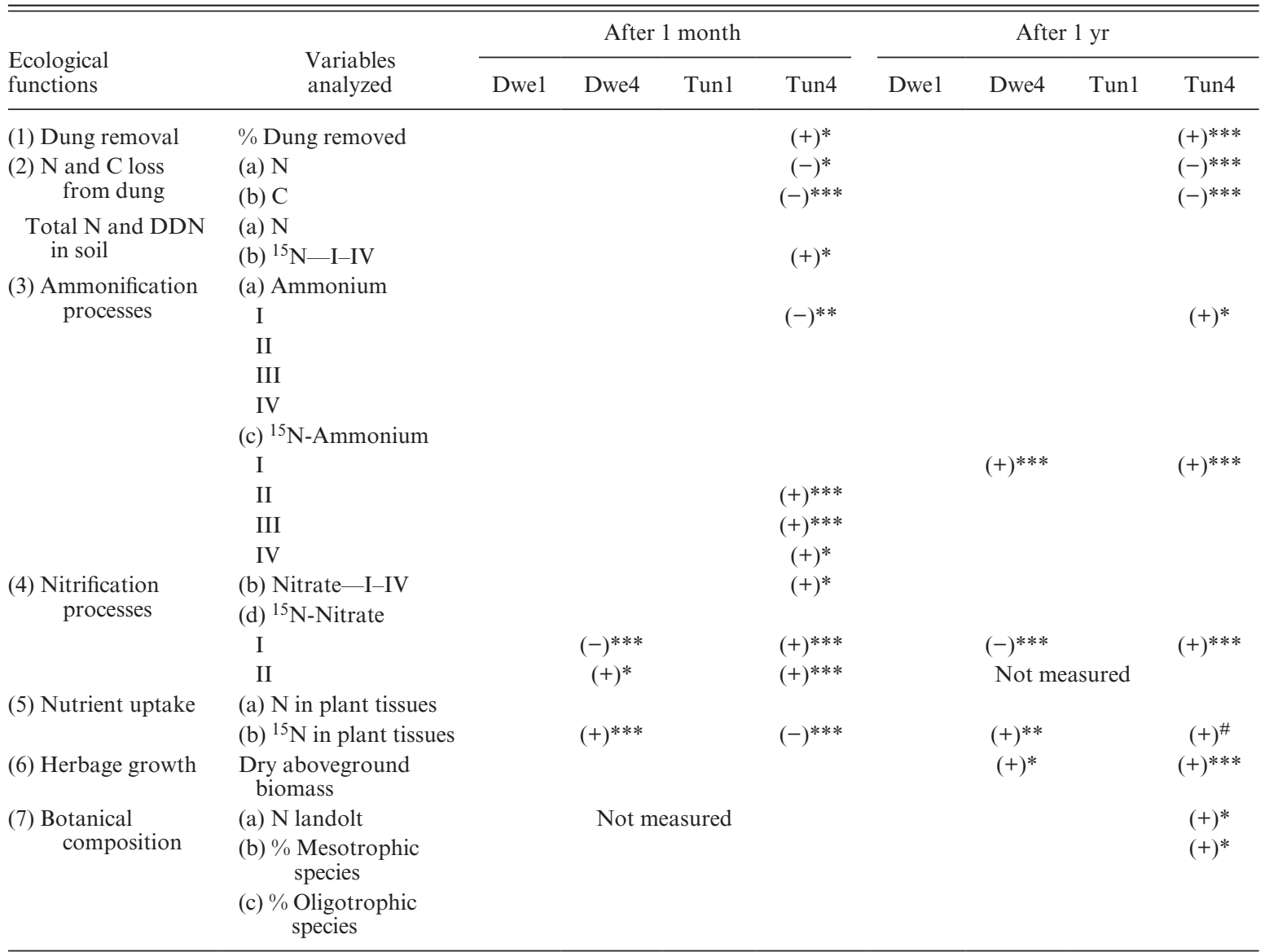

Notes: Results of GLMMs comparing functions between Tun1 (reference level) vs. Tun4, and Dwe1 (reference level) vs. Dwe4 after 1 month, and 1 yr. There were no significant differences between mixed and single- species assemblages after 3 months.

The symbols in parenthesis "+" or "-" refer to the model parameter estimates and indicate if the correlations are positive or negative, while "*" refers to the $P$-values.

Significance codes: $* * * P<0.001 ; * * P<0.01 ; * P<0.05$; ${ }^{*} P=0.05$.

functions operated. Our findings on dung removal are mostly in line with those reported in previous papers (Rosenlew and Roslin 2008, Beynon et al. 2012, Kaartinen et al. 2013, Nervo et al. 2014). Tunnelers were twice as efficient with respect to dwellers in dung removal after 1 month, although this difference was no longer observed after 1 yr. Short-term differences between the two functional groups were mainly linked to their nesting strategies and mean body size (e.g., Nervo et al. 2014). The presence of tunnelers and dwellers led to higher total $\mathrm{N}$ loss from residual dung, probably due to the transport of dung-derived material into the soil in the short term. However, we cannot exclude other $\mathrm{N}$ losses through ammonia $\left(\mathrm{NH}_{3}\right)$ volatilization and/or nitrification/denitrification processes occurring inside the dung pat (Penttilä et al. 2013, Iwasa et al. 2015). In some cases, the presence of dung beetles significantly increased the concentrations of both total and dung-derived $\mathrm{NH}_{4}{ }^{+}$with respect to the dung-only controls after 1 month. This suggests that the transport of dung material along the soil profile may be accompanied by microbially driven ammonification of exogenous organic $\mathrm{N}$ and release of dung-derived $\mathrm{NH}_{4}{ }^{+}$. However, the difference in total topsoil $\mathrm{NH}_{4}{ }^{+}$content between treatments receiving dung and the controls without dung was generally greater than the actual contribution of dung-derived $\mathrm{NH}_{4}{ }^{+}$. This suggests a greater mineralization of soil organic $\mathrm{N}$ in the treatments with dung beetles, highlighting that the priming effect determined by the input of an easily decomposable energy source (Kuzyakov et al. 2000) was further enhanced by beetles. Dung beetles also enhanced both total and dung-derived nitrate $\left(\mathrm{NO}_{3}{ }^{-}\right)$concentrations with respect to the dung-only controls after 1 month in all soil layers, suggesting a significant influence on microbial nitrification processes. This partly involved the nitrification of dung-derived $\mathrm{NH}_{4}{ }^{+}$resulting in a significant ${ }^{15} \mathrm{~N}$ enrichment of the nitrate pool. $\mathrm{NO}_{3}{ }^{-}$concentrations in dung beetle treatments were not higher than controls after $1 \mathrm{yr}$, suggesting that beetles may have only temporarily favored microbial nitrification. 
We expected that mineralization processes would be more enhanced in the presence of tunnelers than dwellers due to their burying activity, but surprisingly both functional groups were similarly efficient. Dung beetle activities may have enhanced microbial activity (Slade et al. 2015) and consequently OM mineralization due to an increase in aerobic conditions inside the dung pat and mainly at the dung-soil interface for dwellers. In contrast to colonized dung, the dung pat without beetles retained moisture and anaerobic conditions for a longer time span (Yokoyama et al. 1991, Bang et al. 2005). These conditions may have delayed mineralization as well as nitrification processes in the control, as confirmed by lower ${ }^{15} \mathrm{~N}_{-} \mathrm{NH}_{4}{ }^{+}$and ${ }^{15} \mathrm{~N}_{-} \mathrm{NO}_{3}{ }^{-}$concentrations compared to the dung beetle treatments after 1 month.

The enhanced $\mathrm{N}$ availability in the topsoil in the presence of dung beetles, as a consequence of enhanced transport and mineralization of dung material, also favored plant $\mathrm{N}$ uptake. Stable isotope analyses of plant tissues found that the presence of dung beetles significantly increased the plant uptake of DDN in presence of both functional groups (especially mixed-species assemblages). However, whereas an increase in plant-available DDN in the presence of dung beetles was already observed after 1 month, the increase in plant DDN was only observed after 3 months and 1 yr. Microbial immobilization of available $\mathrm{N}$ may have competed with plants for nutrient uptake during the first month after dung application, and may have therefore delayed plant uptake of available N. In fact, microbial immobilization is one of the primary mechanisms involved in the retention of mineral $\mathrm{N}$, and the balance between $\mathrm{N}$ mineralization and immobilization depends on the $\mathrm{C}: \mathrm{N}$ ratio of the organic substrate and soil (Hodge et al. 2000).

The effects of dung beetles on nutrient availability and uptake influenced the vegetation. Mixed-species assemblages of tunnelers and dwellers enhanced herbage growth but this increase was observed only after $1 \mathrm{yr}$. This was in accordance with the characteristics of the study area, which was dominated by oligotrophic species (mainly Nardus stricta) that respond less rapidly to variations in fertility compared to mesotrophic species (Fransen et al. 1998). Apparently, our results cannot be extended to all vegetation types (e.g., Yamada et al. 2007). However, the implications of our results may be considered important at a large geographic scale considering that Nardus stricta-dominated grasslands are the most widespread vegetation type in the Western Alps. Changes in soil nutrient availability did not affect the list of plant species but it affected the percentage cover of the plant functional groups (oligotrophic and mesotrophic species). Our results showed that dung beetles significantly influenced the botanical composition of pastures by increasing the cover of mesotrophic species and consequently increasing the weighted average NLandolt. At the same time, the cover of the oligotrophic species remained constant $1 \mathrm{yr}$ after the treatments, probably due to their physiological limitation for $\mathrm{N}$ uptake (Fransen et al. 1998, Lonati et al. 2015). This ecological function, never measured before (Nichols et al. 2008), was provided especially by mixed-species assemblages of tunnelers which were found to greatly increase $\mathrm{N}$ availability in soil and nutrient uptake by plants.

\section{Mixed-species perform better than single-species assemblages}

The influence of mixed and single-species assemblages on the provisioning of ecosystem functions depended on the functional group and the ecosystem functions considered, in addition to the spatial and temporal scales over which the functions operated. As a caveat, we recognize that our experimental design precludes generalizations on the role of diversity in affecting multifunctionality, mainly because the limited number of individuals for each species did not allow us to test all the species in monocultures. However, our results seem to suggest that in most cases the interactions among co-occurring species enhanced ecosystem functions, especially in tunnelers, but see Manning et al. (2016). The tunneler species used in these assemblages had different sizes, and displayed different methods of dung exploitation and diet activity (Halffter and Edmonds 1982, Palestrini and Rolando 2001, Nervo et al. 2014). We hypothesize that different tunnel dimensions, lengths and shapes might have accelerated the transfer of $\mathrm{N}$ from dung to soil and, consequently, nutrient availability for plant uptake. Variation in nesting patterns and body size in mixed assemblages of dwellers may also have been important. The species used in the monocoltures (Teuchestes fossor) was larger than the other dwellers (with the exception of Aphodius rufipes), and exhibited a peculiar soil-ovipositing nesting behavior.

\section{Multiple functions tie into each other over space and time}

Most of the studies over the past decade have used a single-function perspective, or rather addressed the consequence of species loss on single processes (Gamfeldt et al. 2008). The use of single functions as proxies for the overall ecosystem functioning may ignore other important ecosystem processes (Rosenfeld 2002), and be highly misleading, especially if research ultimately aims to provide insights for management and conservation. With a focus on nutrient cycling, in this study we integrated the single functions approach (Byrnes et al. 2014) adopted to evaluate the relationship between diversity and ecological multifunctionality, with a ${ }^{15} \mathrm{~N}$ stable isotope tracing method. The use of ${ }^{15} \mathrm{~N}$ stable isotope tracing allowed us to investigate the complexity of the interlinked ecosystem functions, and to trace the fate of dung-derived $\mathrm{N}$ through the soil $\mathrm{N}$ cycle and its contribution to plant nutrition. We found strong evidence that different ecosystem functions are sequentially interconnected. Indeed, a certain portion of total $\mathrm{N}$ content in soil derived from dung $(<10 \%)$, as well as ammonium $(\sim 38 \%$ at $0-5 \mathrm{~cm}$ after 
1 month) and nitrate ( $67 \%$ at $0-5 \mathrm{~cm}$ after 1 month), showing a strong interconnection among transport, ammonification, and nitrification processes. These processes were found to strongly influence nitrogen uptake: approximately $39 \%, 27 \%$, and $14 \%$, respectively, of dung derived $\mathrm{N}$ contributed to total $\mathrm{N}$ uptake after 1 month, 3 months and $1 \mathrm{yr}$. Consequent changes in herbage growth and botanical composition were evident after 1 yr. Taken together, our current findings offer strong support for the contention that the links between biodiversity and ecosystem functions should be examined not function by function, but in terms of understanding multiple functions and how they interact with each other.

The single functions approach helps to shed light on which and how many processes drive trends in multifunctionality, but additional evidence provided by stable isotope tracing allowed us to evaluate spatial and temporal trends in the processes controlling the fate of dung-derived $\mathrm{N}$. The univariate perspective that addresses single time and space scales has the potential to generate erroneous conclusions about the functional role of biodiversity (Rosenfeld 2002, Duffy et al. 2005, 2007, Srivastava and Vellend 2005, Nichols et al. 2016). For example, mineralization processes were enhanced by beetles after 1 month, but the influence on nutrient uptake and herbage growth were detected only later. In particular, the stable isotope tracing allowed us to reveal functions (e.g., $\mathrm{N}$ uptake by plants) that would have not been evident otherwise.

\section{Conclusions}

Based on our findings, we can highlight important issues in biodiversity and ecosystem functioning research. First, ecosystem functions were found to tie into each other sequentially, giving evidence of the importance of analyzing multiple functions together and not in isolation. Second, applying our current approach of using ${ }^{15} \mathrm{~N}$-isotope tracers to trace multiple functions and their interrelations offers a strong tool for dissecting multiple functions at various spatio-temporal scales. Third, the choice of the variables that describe functions (i.e., $\%$ of dung removed, mineral nitrogen, herbage growth) and the spatio-temporal scale may affect our conclusions on BEF.

\section{ACKNOWLEDGMENTS}

We thank the reviewers for their insightful and constructive comments on an earlier version of this manuscript. We are also grateful to Claudia Tocco, Marco Pittarello, Alberto Berlen, Valeria Guardo, and Emma Pallotta for their useful help in the field and/or in the lab, and to Marcella Sodano, Cristina Lerda, Elena Zanzo, and Paola Gioacchini for their precious support in soil analyses. Special thanks to Dan Chamberlain and Tomas Roslin for their essential suggestions.

\section{Literature Cited}

Allen, V. G., et al. 2011. An international terminology for grazing lands and grazing animals: grazing lands and grazing animals. Grass Forage Science 66:2-28.
Bang, H. S., J. H. Lee, O. S. Kwon, Y. E. Na, Y. S. Jang, and W. H. Kim. 2005. Effects of paracoprid dung beetles (Coleoptera: Scarabaeidae) on the growth of pasture herbage and on the underlying soil. Applied Soil Ecology 29:165-171.

Bardgett, R., and D. A. Wardle. 2010. Aboveground-belowground linkages. Biotic interactions, ecosystem processes, and global change. Oxford University Press, Oxford, UK.

Beynon, S. A., D. J. Mann, E. M. Slade, and O. T. Lewis. 2012. Species-rich dung beetle communities buffer ecosystem services in perturbed agro-ecosystems. Journal of Applied Ecology 49:1365-1372.

Braga, R. F., V. Korasaki, E. Andresen, and J. Louzada. 2013. Dung beetle community and functions along a habitatdisturbance gradient in the Amazon: a rapid assessment of ecological functions associated to biodiversity. PLoS ONE 8:e57786.

Brooks, P. D., J. M. Stark, B. B. McInteer, and T. Preston. 1989. Diffusion method to prepare soil extracts for automated nitrogen-15 analysis. Soil Science Society of American Journal 53:1707-1711.

Byrnes, J., J. S. Lefcheck, L. Gamfeldt, J. N. Griffin, F. Isbell, and A. Hector. 2014. Multifunctionality does not imply that all functions are positively correlated. Proceedings of the National Academy of Sciences USA 5:111-124.

Cardinale, B. J., D. S. Srivastava, J. E. Duffy, J. P. Wright, A. L. Downing, M. Sankaran, and C. Jouseau. 2006. Effects of biodiversity on the functioning of trophic groups and ecosystems. Nature 443:989-992.

Cardinale, B. J., et al. 2011. The functional role of producer diversity in ecosystems. American Journal of Botany 98:572-592.

Cavallero, A., P. Aceto, A. Gorlier, G. Lombardi, M. Lonati, B. Martinasso, and C. Tagliatori. 2007. I tipi pastorali delle Alpi piemontesi. Page 467. A. Perdisa Editore, Bologna, Italy.

Cucu, M. A., D. Said-Pullicino, V. Maurino, E. Bonifacio, M. Romani, and L. Celi. 2014. Influence of redox conditions and rice straw incorporation on nitrogen availability in fertilized paddy soils. Biology and Fertility of Soils 50:755-764.

Daget, P., and J. Poissonet. 1971. Une méthode d'analyse phytologique des prairies. Annales Agronomiques 22:5-41.

Duffy, J. E., B. J. Cardinale, K. E. France, P. B. McIntyre, E. Thébault, and M. Loreau. 2007. The functional role of biodiversity in ecosystems: incorporating trophic complexity. Ecology letters 10:522-538.

Duffy, J. E., J. P. Richardson, and E. A. Canuel. 2003. Grazer diversity effects on ecosystem functioning in seagrass beds. Ecology Letters 6:637-645.

Duffy, J. E., J. P. Richardson, and K. E. France. 2005. Ecosystem consequences of diversity depend on food chain length in estuarine vegetation. Ecology Letters 8:301-309.

Fransen, B., H. De Kroon, and F. Berendse. 1998. Root morphological plasticity and nutrient acquisition of perennial grass species from habitats of different nutrient availability. Oecologia 115:351-358.

Gagic, V., et al. 2015. Functional identity and diversity of animals predict ecosystem functioning better than speciesbased indices. Proceedings of the Royal Society of London B: Biological Sciences 282:20142620.

Gallet, S., and F. Rozé. 2001. Resistance of Atlantic Heathlands to trampling in Brittany (France): influence of vegetation type, season and weather conditions. Biological Conservation 97:189-198.

Gamfeldt, L., H. Hillebrand, and P. R. Jonsson. 2008. Multiple functions increase the importance of biodiversity for overall ecosystem functioning. Ecology 89:1223-1231.

Halffter, G., and W. D. Edmonds. 1982. The nesting behavior of dung beetles (Scarabaeinae). An ecological and evolutive approach. Instituto de Ecologia, Mexico. 
Hector, A., and R. Bagchi. 2007. Biodiversity and ecosystem multifunctionality. Nature 488:188-190.

Hodge, A., D. Robinson, and A. Fitter. 2000. Are microorganisms more effective than plants at competing for nitrogen? Trends in Plant Science 5:304-308.

Hooper, D. U., et al. 2005. Effects of biodiversity on ecosystem functioning: a consensus of current knowledge. Ecological Monographs 75:3-35.

IPLA. 2007. Carta dei Suoli del Piemonte (1:250.000). Selca, Firenze, Italy.

Iwasa, M., Y. Moki, and J. Takahashi. 2015. Effects of the activity of coprophagous insects on greenhouse gas emissions from cattle dung pats and changes in amounts of nitrogen, carbon, and energy. Environmental Entomology nvu023:1-8.

Kaartinen, R., B. Hardwick, and T. Roslin. 2013. Using citizen scientists to measure an ecosystem service nationwide. Ecology 94:2645-2652.

Kohler, F., F. Gillet, J. M. Gobat, and A. Buttler. 2004. Seasonal vegetation changes in mountain pastures due to simulated effects of cattle grazing. Journal of Vegetation Science 15:143-150.

Kuzyakov, Y., J. K. Friedel, and K. Stahr. 2000. Review of mechanisms and quantification of priming effects. Soil Biology and Biochemistry 32:1485-1498.

Landolt, E., et al. 2010. Flora indicativa. Ecological indicator values and biological attributes of the flora of Swizterland and the Alps. Haupt Verlag, Bern, Switzerland.

Lefcheck, J. S., J. E. K. Byrnes, F. Isbell, L. Gamfeldt, J. N. Griffin, N. Eisenhauer, M. J. S. Hensel, A. Hector, B. J. Cardinale, and J. E. Duffy. 2015. Biodiversity enhances ecosystem multifunctionality across trophic levels and habitats. Nature Communications 6:1-7.

Lonati, M., A. Gorlier, D. Ascoli, R. Marzano, and G. Lombardi. 2009. Response of the alien species Panicum acuminatum to disturbance in an Italian lowland heathland. Botanica Helvetica 119:105-111.

Lonati, M., M. Probo, A. Gorlier, and G. Lombardi. 2015. Nitrogen fixation assessment in a legume-dominant alpine community: comparison of different reference species using the $15 \mathrm{~N}$ isotope dilution technique. Alpine Botany 125:51-58.

Maestre, F. T., A. P. Castillo-Monroy, M. A. Bowker, and R. Ochoa-Hueso. 2012. Species richness effects on ecosystem multifunctionality depend on evenness, composition and spatial pattern. Journal of Ecology 100:317-330.

Manning, P., E. M. Slade, S. A. Beynon, and O. T. Lewis. 2016. Functionally rich dung beetle assemblages are required to provide multiple ecosystem services. Agriculture, Ecosystems \& Environment 218:87-94.

McCune, B., and M. J. Mefford. 1999. PC-ORD. MjM Software Design, Gleneden Beach, Oregon, USA.

Mouillot, D., S. Villeger, M. Scherer-Lorenzen, and N. W. H. Mason. 2011. Functional structure of biological communities predicts ecosystem multifunctionality. PLoS ONE 6:e17476.

Mucina, L., G. Grabherr, and T. Elmajer. 1993. Die Pflanzengesellschaften Österreichs, Teil2 Natürliche waldfreie Vegetation. Gustav Fischer, Jena, Stuttgart, Germany; New York, New York, USA.

Naeem, S., J. E. Duffy, and E. Zavaleta. 2012. The functions of biological diversity in an age of extinction. Science 336: 1401-1406.

Nervo, B., C. Tocco, E. Caprio, C. Palestrini, and A. Rolando. 2014. The effects of body mass on dung removal efficiency in dung beetles. PLoS ONE 9:e107699.

Nichols, E., C. A. Peres, J. E. Hawes, and S. Naeem. 2016. Multitrophic diversity effects of network degradation. Ecology and Evolution 6:4936-4946.
Nichols, E., S. Spector, J. Louzada, T. Larsen, S. Amezquita, M. E. Favila, and T. S. R. Network. 2008. Ecological functions and ecosystem services provided by Scarabaeinae dung beetles. Biological Conservation 141:1461-1474.

O'Hea, N. M., L. Kirwan, and J. A. Finn. 2010. Experimental mixtures of dung fauna affect dung decomposition through complex effects of species interactions. Oikos 119:1081-1088.

Palestrini, C., and A. Rolando. 2001. Body size and paternal investment in the genus Onthophagus (Coleoptera, Scarabaeoidea). Journal of Zoology 255:405-412.

Penttilä, A., E. M. Slade, A. Simojoki, T. Riutta, K. Minkkinen, and T. Roslin. 2013. Quantifying beetle-mediated effects on gas fluxes from dung Pats. PLoS ONE 8:1-7.

Peter, H., I. Ylla, C. Gudasz, A. M. Romaní, S. Sabater, and L. J. Tranvik. 2011. Multifunctionality and diversity in bacterial biofilms. PLoS ONE 6:e23225.

Probo, M., A. Massolo, M. Lonati, D. W. Bailey, A. Gorlier, L. Maurino, and G. Lombardi. 2013. Use of mineral mix supplements to modify the grazing patterns by cattle for the restoration of sub-alpine and alpine shrub-encroached grasslands. Rangeland Journal 35:85-93.

R Development Core Team. 2013. R: a language and environment for statistical computing. R Foundation for Statistical Computing, Vienna, Austria. http://www.R-project.org

Reiss, J., J. R. Bridle, J. M. Montoya, and G. Woodward. 2009. Emerging horizons in biodiversity and ecosystem functioning research. Trends in ecology and evolution 24:505-514.

Rosenfeld, J. S. 2002. Functional redundancy in ecology and conservation. Oikos 98:156-162.

Rosenlew, H., and T. Roslin. 2008. Habitat fragmentation and the functional efficiency of temperate dung beetles. Oikos 117:1659-1666.

Schleppi, P., I. Bucher-Wallin, M. Saurer, M. Jäggi, and W. Landolt. 2006. Citric acid traps to replace sulphuric acid in the ammonia diffusion of dilute water samples for $15 \mathrm{~N}$ analysis. Rapid Communications in Mass Spectrometry 20: 629-634.

Shepherd, M. J., J. M. Anderson, R. Bol, and D. K. Allen. 2000. Incorporation of $15 \mathrm{~N}$ from spiked cattle dung pats into soil under two moorland plant communities. Rapid Communications in Mass Spectrometry 14:1361-1367.

Slade, E. M., D. J. Mann, J. F. Villanueva, and O. T. Lewis. 2007. Experimental evidence for the effects of dung beetle functional group richness and composition on ecosystem function in a tropical forest. Journal of Animal Ecology 76:1094-1104.

Slade, E. M., and T. Roslin. 2016. Dung beetle species interactions and multifunctionality are affected by an experimentally warmed climate. Oikos 125:1607-1616.

Slade, E. M., T. Roslin, M. Santalahti, and T. Bell. 2015. Disentangling the 'brown world' faecal-detritus interaction web: dung beetle effects on soil microbial properties. Oikos 000:001-007.

Speight, M. R., M. D. Hunter, and A. D. Watt. 1999. The ecology of insects: concepts and applications. Blackwell Science, Oxford, UK.

Srivastava, D. S., and M. Vellend. 2005. Biodiversity-ecosystem function research: is it relevant to conservation?. Annual Review of Ecology, Evolution, and Systematics 36: 267-294.

Stark, J. M., and S. C. Hart. 1996. Diffusion technique for preparing salt solutions, Kjeldahl digests, and persulfate digests for nitrogen-15 analysis. Soil Science Society of American Journal 60:1846-1855.

Tasser, E., and U. Tappeiner. 2005. New model to predict rooting in diverse plant community compositions. Ecological Modeling 185:195-211. 
Tixier, T., J. M. Bloor, and J. P. Lumaret. 2015. Species-specific effects of dung beetle abundance on dung removal and leaf litter decomposition. Acta Oecologica 69:31-34.

Tocco, C., M. Negro, A. Rolando, and C. Palestrini. 2013. Does natural reforestation represent a potential threat to dung beetle diversity in the Alps? Journal of Insect Conservation 17: 207-217.

Wardle, D. A. 2002. Communities and ecosystems: linking the aboveground and belowground components. Princeton University Press, Princeton, New Jersey, USA.

Yamada, D., O. Imura, K. Shi, and T. Shibuya. 2007. Effect of tunneler dung beetles on cattle dung decomposition, soil nutrients and herbage growth. Grassland Science 53:121-129.
Yokoyama, K., H. Kai, T. Koga, and T. Aibe. 1991. Nitrogen mineralization and microbial populations in cow dung, dung balls and underlying soil affected by paracoprid dung beetles. Soil Biology and Biochemistry 23: 649-653.

Zavaleta, E. S., J. R. Pasari, K. B. Hulvey, and G. D. Tilman. 2010. Sustaining multiple ecosystem functions in grassland communities requires higher biodiversity. Proceedings of the National Academy of Sciences USA 107: $1443-1446$.

Zuur, A. F., E. N. Ieno, N. J. Walker, A. A. Saveliev, and G. M. Smith. 2009. Mixed effects models and extensions in ecology With R. Springer, Berlin, Germany. 